$\pm N$

Global Journals Inc.

in

GLOBAL JOURNAL OF HUMAN-SOCIAL SCIENCE: H

INTERDISCIPLINARY

Volume 20 Issue 11 Version 1.0 Year 2020

Type: Double Blind Peer Reviewed International Research Journal

Publisher: Global Journals

Online ISSN: 2249-460x \& Print ISSN: 0975-587X

\title{
Family and Conjugality: Perception of Happiness of Domestic Abusers
}

By Dóris Cristina Gedrat, Eliane Fraga Da Silveira, Honor De Almeida Neto, Gehysa Guimarães Alves \& Ângela Maria Pereira Da Silva

Lutheran University of Brazil

Abstract- This research aimed to learn about the happiness perception of men with violent behavior, attended by a nucleus of assistance to victims of violence in the metropolitan region of Porto Alegre, RS, Brazil. For this, 16 men with restraining orders for assaulting their partners (Lei Maria da Penha - 11.340/2006) were interviewed. This study involved descriptive research (qualitative approach), and data were analyzed using thematic content analysis. For the discussion, three subcategories related to Subjective Well-Being were organized into: conception of happiness, challenges in being happy, and attitudes required in being happy. The word "family" was referenced by abusers in all subcategories. When it comes to involving violence between intimate partners, this new approach intends to make men a part of the solution rather than just the problem.

Keywords: happiness, domestic violence, aggression, family network, the bond between partners.

GJHSS-H Classification: FOR Code: 940112

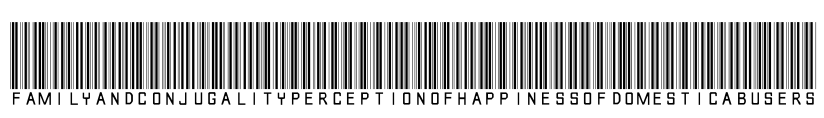

Strictly as per the compliance and regulations of:

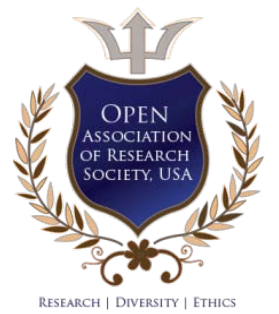

(C) 2020. Dóris Cristina Gedrat, Eliane Fraga Da Silveira, Honor De Almeida Neto, Gehysa Guimarães Alves \& Ângela Maria Pereira Da Silva. This is a research/review paper, distributed under the terms of the Creative Commons AttributionNoncommercial 3.0 Unported License http://creativecommons.org/licenses/by-nc/ 3.0/), permitting all non-commercial use, distribution, and reproduction in any medium, provided the original work is properly cited. 


\title{
Family and Conjugality: Perception of Happiness of Domestic Abusers
}

\author{
Dóris Cristina Gedrat ${ }^{\alpha}$, Eliane Fraga Da Silveira ${ }^{\circ}$, Honor De Almeida Neto ${ }^{\circ}$, Gehysa Guimarães Alves ${ }^{\omega}$ \\ \& Ângela Maria Pereira Da Silva ${ }^{*}$
}

Abstract This research aimed to learn about the happiness perception of men with violent behavior, attended by a nucleus of assistance to victims of violence in the metropolitan region of Porto Alegre, RS, Brazil. For this, 16 men with restraining orders for assaulting their partners (Lei Maria da Penha 11.340/2006) were interviewed. This study involved descriptive research (qualitative approach), and data were analyzed using thematic content analysis. For the discussion, three subcategories related to Subjective Well-Being were organized into: conception of happiness, challenges in being happy, and attitudes required in being happy. The word "family" was referenced by abusers in all subcategories. When it comes to involving violence between intimate partners, this new approach intends to make men a part of the solution rather than just the problem.

Keywords: happiness, domestic violence, aggression, family network, the bond between partners.

\section{INTRODUCTION}

$\mathrm{n}$ recent decades, despite the economic growth and the increased life expectancy of citizens, the levels of happiness and well-being have stagnated in several countries. Consequently, Gross Domestic Happiness has received increasing attention, along with new metrics for progress that consider social, environmental, spiritual, and economic dimensions. Several researchers worldwide have become interested in the theme of happiness, to signal the development of public policies, aimed at increasing wellbeing (Brissos-Lino, 2015, Sarriera \& Bedin, 2017).

Allied to the concept of Gross internal happiness is the reality of inequality among diversities. The more asymmetrical the feeling of satisfaction among people, the unhappier the entire population will be, since inequality brings devastating effects for individuals and the collectives, instigating crime, psychological suffering, and armed conflict (BrissosLino, 2015). One prevalent form of inequality is inequality in marital relations. Women are often considered inferior and therefore deserving of unfair and often abusive treatment.

As for the abusers in intimate relationships, before becoming victimizers, they themselves were victims of abuse; this repetitive pattern in relationships leads them to live deeply unhappy, even without being aware of it (Musleh, 2013). Thus, this study aimed to understand the happiness perception of men with

Author a: Lutheran University of Brazil. e-mail: doris.gedrat@ulbra.br violent behavior, attended by a nucleus of assistance to victims of violence in a city in the metropolitan region of Porto Alegre in Rio Grande do Sul. Further, we investigate the correlation between the act of assault and the abuser's perception of happiness. We sought to identify which determinants influence individuals to consider themselves happy and which attitudes influence the achievement of their happiness, in order if assault has an influence on subjective, emotional, spiritual, and physical well-being of these participants in the study and how assault is related to their marital wellbeing.

\section{a) Happiness as subjective well-being}

Subjective well-being comprises three dimensions: positive affections, negative affections, and satisfaction with life (Castaños-Cervantes, SánchezSosa, 2015; Lima, Araujo, 2018). According to these authors, positive affection is defined by a transitory feeling, it is momentary and presents itself as a state of alertness, enthusiasm, and activity; negative affection is manifested by unpleasant transitory emotions, including anxiety, depression, agitation, boredom, pessimism; and satisfaction with life is the cognitive judgment about one's own life, compared to a pattern chosen by the individual.

The explanatory models on well-being and happiness have been transformed since the 1960s, from new theories and epistemologies, with methodological, scientific, and academic developments. Sarriera and Bedin (2017) defend the importance of treating wellbeing as a multidimensional category. Their theory is based on human rights, considering the person as an integral being in its biopsychosocial, cultural, moral, and spiritual aspects. This is the principle of the indivisibility of the individual with his or her vital environment. Wellbeing is built on the daily interaction of the individual with the environment. That is why it is important to propose a multidimensional model that approaches general well-being, considering the different dimensions and indicators. According to the authors, it is necessary to have approaches that integrate subjective and objectives indicators of well-being, as well as from an individual perspective to a biopsychosocial and community perspective.

From this perspective, Sarriera and Bedin (2017) point to the need for approaches that integrate 
subjective and objective welfare indicators. Their multidimensional proposal subdivides well-being into four subcategories: subjective well-being, psychological well-being, psychosocial well-being, and sociocommunity well-being. Subjective well-being refers to the assessments that people make of their lives in cognitive and affective terms, representing beliefs and feelings about how rewarding their lives are. It can be understood as a consequence of the interaction between internal aspects and external interactions of people with others and with the environment (Homes, 2011).

Psychological wellbeing refers how a person functions. According to Ryff (1989), it is operated in six dimensions: autonomy, life purpose, self-acceptance, positive relationships with others, environmental control, and personal growth. In psychosocial well-being, the authors include interpersonal relationships, leisure, and the use of technology. Family relationships initiate socialization, serve as a basis for future relationships, and influence development and well-being. Activities involving social interaction and the development of physical and intellectual abilities, although inserted in psychological well-being, are also signs of subjective well-being.

Finally, on social-community well-being, the authors explain that satisfaction with life is more present in societies with less social inequalities (Veenhoven, 2009) and is present in fellowships that guarantee freedom and encourage participation in the community (Sen, 1996). For Castel (1988, p. 59), this participation would refer to "the forms of belonging to one's family, neighborhood, working group, with its networks of interdependence, without the mediation of specific institutions and secondary protection, deined as the place of the institutions created for those who are disconnected from the networks of primary sociability."

\section{b) Happiness and domestic violence in relationships}

In many families, verbal and physical abuse, retaliation, power games, and anger favor an environment with less flexibility and dialogue, more rigidity in relationships and roles, and more conflicts (Meneghel et al, 1998). According to Narvaz and Koller (2006, p. 8), "domestic violence is conceived as any kind of violence that includes members of a group, sharing non-parental roles with each other, who live in the domestic space, including people who live sporadically in this space." The authors highlight the cross-generational transmission of violence, the naturalization of gender-stereotyped roles, alcoholism, poverty, and the lack of social support as factors associated with the processes of submission and subjugation of women to the violence suffered.

The probable justifications for the occurrence of violence are based on certain social and, above all, individual needs, such as lack of self-love and love for the other person, lack of a positive attitude, and lack of basic conditions. As for the consequences, the occurrence of violence generates feelings of fear, insecurity, indignation, and suffering, which harm the lives of these women, interfering with their ability to live harmoniously. From this point of view, thinking about actions to promote quality of life is a strategy that can be effective in confronting violence against women (Palhoni et al, 2017).

This study, focuses on men who assault their partners. According to a study conducted in a city in Paraná (Madureira et al, 2014), the profile of these men is young adults, married, and with paid work and low schooling. Among those reported, almost 90\% assaulted their partner under the influence of alcohol and many had previous records of domestic violence. There were no records of studies interested in verifying the influence of the abuser in the perception of happiness and the role of conjugal understanding in the conception of happiness of these men. These are the focus questions of this study.

Although there is no justification for violent abusive behavior in a relationship (Zuwick, 2001), Musleh (2013) observed a repetitive pattern of violence among sexual victimizers. The author found that $98 \%$ of the victimizers he assisted were victims of sexual abuse in childhood, reproducing this violent practice. As a result, it is justified to treat the victimizer, who was also a victim, with this being a viable alternative, in addition to attending to the victims, creating the possibility of solving this problem, offering new direction to the perpetrators, to understand this social issue, helping them leave the cycle of violence behind (Musleh, 2013).

From this perspective, this study assumed that the happiness of men with violent behavior is closely related to their ability to free themselves from the cycle of violence that persists in their lives, healing the pains of the past and ceasing such behavior against their intimate partner and sometimes their children as well, who may witness the abuse. For this, services aimed at interrupting the perverse cycle of violence by enabling the abuser to recognize his difficulty and creating instruments to deal with it are needed. This will open a space for the deconstruction of a marginalizing position, as well as opening possibilities for him to build a new persona in his family life (Musleh, 2013).

Violence against women is closely linked to socio-cultural and religious patterns and customs and is a consequence of the historical gender inequality established within societies and power structures (ALMG, 2018). The stereotyped gender roles conveyed by culture through the family turn a blind eye to both production and reproduction of female subordination, a fertile ground for abuse (Narvaz and Koller, 2004). In the face of this, violence against women is trivialized, minimized, denied, and even naturalized by the sexist culture (Strey, 2000). 
An important achievement for the confrontation of violence against women in Brazil was the declaration of the Maria da Penha Law (Federal Law no 11.340, of August 7,2006$)$, which created mechanisms to restrain and prevent domestic and family violence and established assistance and protection measures. However, despite the progress and protection brought about by the law, the data remains alarming. Moreover, it is essential to promote research to describe the characterization of men with violent behavior and the factors associated with violence, since these elements can contribute to the development of prevention strategies and public policies of attention for implementation in the Networks of Assistance and Fighting Violence. (Madureira et al., 2014). For professionals and other legal operators and society in general to develop intervention measures for the prevention and promotion of the health of those involved, it is necessary to understand the profile of the abuser and the factors associated with violence (Vasconcelos et al., 2016).

\section{il. Methodology}

This study involved exploratory descriptive research, with a qualitative approach, in which one tries to understand if the participating men perceive themselves as happy, what prevents them from achieving happiness and what do they do to attain it. To achieve the objectives, 16 men with restraining orders (Maria da Penha Law - 11.340/2006) for abuse against their partners, were interviewed. These men were assisted at the Nucleus of Assistance to Victims of Violence in the city, participating in a weekly forum for reflection, with psychological follow-up, in which they discussed the events of their lives and the violence practiced by them. At the end of this stage, they accepted to be interviewed and participate in this research.

The interviews were conducted in December 2018. Each interviewee was directed to a room where, individually, he was interviewed by two researchers, who recorded the interviews for later analysis. The participants' responses were analyzed using the thematic content analysis method (Minayo, 2014).

When comparing the data collected with the Multidimensional Approach to Well-Being, given by Sarriera, and Bedin (2017), the content associated with the subjective well-being category was identified, although some elements found were included in psychological well-being, psychosocial well-being, or social-community well-being. Thus, the analysis focused on the subjective well-being category, also including the elements described as belonging to the other three. Three subcategories related to the basic category were constructed: conception of happiness, challenges in being happy, and attitudes to being happy. The record units were then analyzed around the dimensions of the relationship with oneself, relationship with others, and occupation, creating codes that would represent them.

The research was submitted to the Research Ethics Committee of the Lutheran University of Brazil (ULBRA), under the number 70727817.8.0000.5349, and approved under the opinion number 3.087.687. The study followed the required ethical standards. The autonomy and privacy of the participants were respected. Further, all the participants signed the Free and Informed Consent Form (FICF). To preserve anonymity, the interviewees were identified by the letter $\mathrm{P}$ (of participant), followed by a number. 


\section{ili. Results and Discussion}

This survey included adult men, aged 27 to 68, with 25\% between 27 and 33, 37.5\% between 40 and 45, and $37.5 \%$ between 56 and 68 .

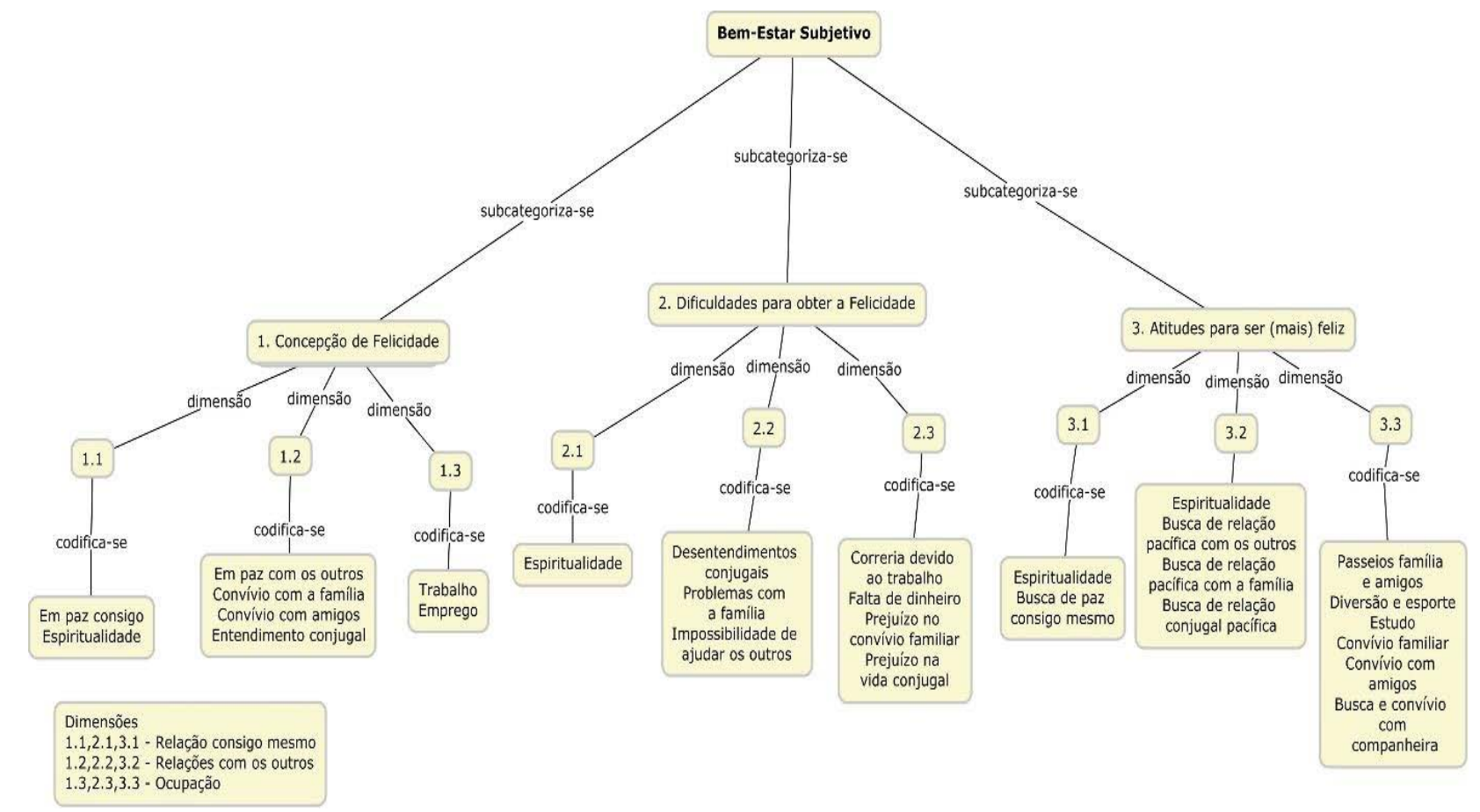

Source: The research

Figure 1: Conceptual map of codes resulting from the thematic analysis of the subjective well-being category proposed by Sarriera and Bedin (2017), a result of interviews with 16 men with restraining orders

Figure 1 summarizes the results, organized based on the subjective well-being category, by Sarriera and Bedin (2017), subcategorized as, conception of happiness (1), challenges in being happy (2), and attitudes to be (more) happy (3). Within these subcategories, each textual unit was classified in one of the dimensions of the tripod relationship with oneself, relationships with others, and occupation.

\section{Conception of Happiness}

When asked what they understand by happiness, the interviewees referred, in the dimension of their relationship with themselves, to two codifications: being well with themselves and spirituality/selfknowledge. As the following statements show, the interviewees see happiness closely connected with the feeling of well-being with themselves.

"First with, yeah, like, if I am not well with me, I won't be happy." (P11).

"Me, and I think all people being ok with themselves in the first place." (P15).

"Happiness is a sensation of well-being, of a clear conscience, yes." (P13).

These narratives can be correlated to the conception of Medrado et al (2010), regarding the emergence of political rationalities, through diverse authorities that act from (and in) different contexts, in search of certain objectives, strategies in which the technologies of "self-government" are included, through which (and in) people structure conducts, thoughts, experiences, understandings, and systems of judgment about themselves.

Participant P13's response about being of a clear conscience as part of being well with oneself, indicates that one needs to analyze themselves and review their own attitudes. This was done in the Reflection Forum in which the interviewees participated during the semester before the survey. According to Musleh (2013), this is a service where the goal is to help the victimizer, who, in most cases of abusers who seek help, was once a victim himself.

For Ryf (1989), the full functioning of the person is operationalized in six dimensions: autonomy, life purpose, self-acceptance, positive relationships with others, environmental control, and personal growth. For this author, optimal well-being (high level of subjective well-being and psychological well-being) increases with age, education, extroversion, and an increase of consciousness and decreases with neuroticism (characterized by sadness). This was evident when the interviewees mentioned that happiness also means 
relating well with others, with emphasis on family relationships and coexistence, and this is one of the dimensions highlighted in the definition of subjective well-being by Sarriera and Bedin (2017). Despite referring to others, the statements of the interviewees again reflect the concern to put into practice an acquired knowledge, that is, that each one should make an effort to create good relationships, each one should do their part; and this involves eliminating abuse and disagreement. More than eliminating violent ways of living together, P12 pointed out the need to wish the well-being of others:

"I think that the greatest happiness is this: if you get along well, wish your neighbor well, since we wish good things for us, we wish good things for our neighbors too, right?"

"We already feel happy when we see a person well..." (P12)

The subject of family is very prominent among those interviewed, as is their relationship with their intimate partner, whether conjugal or not. P12 believes that dialogue with the partner is fundamental. P3 and P9 referred to the importance that the family has for them, as indicated in the statements below; this is interesting as the participants are abusers of their partners. Foucault (1994) understands the notion of government as a relationship between subjects, that is, the set of actions on possible actions, behavior that has as objective the behavior of another individual or groups, and the government as a relationship with oneself. Thus, the modes of subjectivation-objectivation are situated at the intersection of the two axes.

"Ah, for me, happiness, as I am married, is to be well with my family, yes, with my wife, with my children, yes, always trying to get along with my relatives and [...]" (P3).

"To be happy is to live with my family. For me, nothing makes me happier than living with my family." (P9).

$\mathrm{P} 11$, as in the response below, attributed happiness to work, confirming Fernandes and Ferreira's (2015) conclusions, about work being essential in the evaluation that an individual makes about his/her subjective well-being, about his/her happiness, since it interferes in the way the person lives and faces his/her life. In this regard, Barker (2010) addresses the work imperative for men to exercise masculinity, directly related to production possibilities. The non-fulfillment of this launches them into situations of shame, stress, and depression, among others.

"[...] with all the universe I deal with, the people, ... the work... for me this is happiness, being happy." (P11).

In a study on well-being at work, the importance of self-realization for well-being is highlighted, invoking the eudemonic conception of well-being (Soraggi and
Paschoal, 2011). Eudaemony refers to the subjective state when the individual develops his potentials and moves towards his life's purposes, which leads to selfrealization (Waterman, Schwartz, Conti, 2008). In the same sense, for Paschoal (2008), happiness is centered on the experiences of personal expression and selfrealization, as demonstrated by P16's response:

"To see my client's satisfaction. That makes me happy. And look, and think something like: "Wow, that got better than I thought it would," you know? That compliment, or that, I think would be his satisfaction... That makes me happy." (P16).

For Barker (2010) it seems quite obvious to affirm that the role of provider, the man of the household or "working man" (for whom masculinity is defined as having a job), is perhaps a universal, that is, the way in which societies, institutions, individuals, and public policies universally define adult masculinity. This author also points out that, focusing specifically on work and men, policies, for the most part, are blind when they come to this equation of work and masculinity. In other words, we can also state that they assume that men are just workers or categorize all men together, that is, those of low income, destitute, of middle class and those who have a stable job and income (Barker, 2010).

\section{Challenges in Being Happy}

It can be seen from the answers of those interviewed that they attribute a good part of their difficulty in achieving happiness to themselves, which leads one to believe that they consider happiness to be something within oneself, and it is up to them to find it. Considering that life and feelings change all the time, individuals sometimes perceive their well-being positively, and sometimes they feel dissatisfied with life. Even so, the most comprehensive judgment they make about their own life continues to exist (CastañosCervantes, Sánchez-Sosa, 2015; Lima, Araujo, 2018). In the dimension of the relationship with oneself, the participants mentioned their participation in the conjugal relationship as a barrier to being happy. Although they find it more difficult to talk about this subject, they mentioned that disagreements never occur because of one, that the couple ends up dealing with each other in a way that is not good for them. P1's response exemplifies this.

"It's a lot of things, which I honestly prefer not to get into because I have an opinion about people who live together. The person, my companion, in this case, made a big mistake with me and I also made a mistake with her. We have been together for over 40 years. So, for her to stay this time with me, she has to see something good in me, and I have to see something, otherwise, I wouldn't be with her until today, right?" (P1). 
P13 already commented that he became very depressed in a phase of his life, which led to alcohol abuse, further leading to relationship problems and abuse,

"Yeah, I started on the wrong track. And I got very depressed, and I was abusing alcohol too, in addition to that." (P13).

That is discussed by Scott:

"The affirmation of male control goes over the female body and is often performed in states of drunkenness or at times of greater pressure, outside the home. It is usually associated with a man's fear of the implication of greater social circulation of his wife that makes his control over her activities, and especially her sexual relations, questionable." (Scott, 2010, p. 89).

Another aspect observed deals with the relationship of the interviewees with others, generally reported the relationship with the partner. Whether it is assuming a part of the responsibility or attributing to her or drastically diminishing the importance and seriousness of themselves as abusers, attributing the cause of the fights to the woman's insecurity.

"Look, I believe are the fights and stuff. With all due respect to my wife, she has a problem that is quite big: she's gonna say something to you, instead of her saying something calmly, relaxed, she starts "BIBIBI," you know? What for? Speak nicely, easy, you don't have to do that, right?" (P14).

In that sense, Toneli claims that:

"What can we talk about the practices of intimacy in this scenario, in which the "intimate" relationships themselves are regulated, standardized? The delay even in recognizing the seriousness of the situation of violence against women in the "domestic" sphere demonstrates, on the other hand, the articulation between what is understood as private and public, both marked by the sexual division that produces/ naturalizes/legitimate forms of being in the world. Dissonant masculinities are also the permanent target of suspicion, of attempts at regulation, of violence, suggesting that the "private" is a place of vulnerability for men and women subjected to normative violence." (Toneli, 2010, p. 147).

This is evidenced in the account by participant P16, as he felt humiliated, pressured to monitor his partner's behavior after an affair. In other words, he relativized aggression and blamed the woman for stressful and conflicting situations:

"I was no abuser. I may have assaulted with just one word, and what I got was the door slammed in my face because I was... it was a girlfriend I had, and I saw her coming out of a motel, you know? And what happened is that I went to her house, we had scheduled it and everything, and I looked at her and asked: "you have nothing to tell me?" "no, I don't," "but I have, I saw you leaving the motel," like this." (P16).

For Saffioti (1994) it is not being said that women are holy because they participate in the relationship of violence and even trigger it. However, women hold the same power as men. It is a correlation of forces that rarely benefits women, that is, the negative balance of gender violence is tremendously more negative for women than for men. Authors Pinto, Meneghel, and Marques (2007) point out that violence can no longer be naturalized, nor accepted. For that, profiling the abuser is important and urgent for the understanding of the several collaborating factors associated with men's acts of violence against women.

Cecarelli (1998) points out that the patterns of masculinity in a man can be assessed from his experiences from childhood, family, school, and with friends. Together they form the primary framework of "male socialization," that is, processes that guide them in shaping what it is to be a man. In this way, the relationship with their children also comes to the fore when those interviewed talk about what prevents them from being happy. Some refer to missing their children, others to the conflicts among relatives, as pointed out by P3 and P8:

"Well, sometimes it's worrying about a son, about the wife; I have a little boy who is autistic, so sometimes he has a crisis, so that makes us very sad." (P3).

"[...] at the moment, I have to help my sister. She's going to college, she doesn't work, and I have to support her. She lives with me, right? And then I have to pay for everything. After she graduates, we'll see what we'll do. Maybe she'll help me." (P8)

Besides the relationship between the couple and other family members, what prevents the achievement of happiness, according to those interviewed, is the daily agitation and the lack of time organization, which leads them to dedicate themselves almost entirely to work and obligations, leaving relationships, especially family ones, aside. Again, interviewees sometimes recognized that they triggered the barrier to happiness. They referred to the lack of time due to work, little money to do what they would like, as P2, P5, and P6 point out:

"I believe that the responsibilities of everyday life, such as challenges in teaching, difficulty in studying, college, paying bills, things like that." (P2).

"Ah, nowadays, it would be the financial life, yes, mainly. It's not easy for anyone. So, it's one of the barriers that make it difficult... You have to fight for it." (P5).

"[...] then that is... lack of money makes you unhappy... not being able to do something at work makes you sad... that ends up affecting you, your hurry in the pursuit of happiness." (P6). 
Bustamente (2005) points out that the context of the "new father," through which fatherhood is considered an opportunity to express feelings, participating actively in childcare, and having an egalitarian and fluid relationship with the partner, involves the division of tasks. For this author, men have bear conflicting expectations, that is, on one hand they actively participate in the economic sphere and are providers of the family, while on the other hand they are required to be present at home. In this way, they share the burden of childcare with their partners, but in the multiplicity of ways of exercising paternity, linked to various social and cultural processes.

Some interviewees (P11 and P12) denied having challenges in being happy and claimed that there was nothing wrong with their life. They said they solve problems normally when obstacles arise.

"Look, nothing gets in my way because the obstacles in life have to be solved little by little, I think that there is no problem; at least I think that way, right." (P11).

"Thank God I have nothing to complain about." (P12).

According to Ryff (1989), age and increasing awareness help in subjective well-being, which can be related to the way problems being seen as momentary, and not influencing happiness.

\section{Vi. Attitudes Reguired in Being Happy}

To achieve happiness, in the dimension of wellbeing with oneself, the interviewees made several references to spirituality. This is an important dimension of many people's lives and should be considered, for example, in the evaluation of health processes and quality of life, along with the biological, psychological, and social dimensions (Lucchetti and Lucchetti, 2014; Sarriera, 2004). It refers to the internal belief system that brings strength and comfort to people. This is different from religiosity, which refers to rituals and practices adopted according to a specific religious belief (Houskamp, Fisher and Stuber, 2004). Some interviewees, such as P13 and P16, also related their spirituality and self-reflection to the self-knowledge they have acquired with these practices, as shown in their accounts below. They reflected the importance of understanding how they act, and why they act in a particular way.

"It's, to try to understand why things happened, the way things happened, why I got out of control, actually... so that's how I found myself." (P13).

"Yeah, that's right. It's like I always say, sometimes you go there, so even now, the pastor reads a text, but he's talking to me." (P16).

P1 and P14 mentioned that they invest in the relationship and in living with family and friends, mainly children and partners, to feel happy. It was common for them to express that their commitment to making these people feel good brings them well-being and happiness. However, happiness is not something built from the outside in. It needs investment in oneself so that one can know oneself and act toward what one desires. When a person desires/values what they have, they are making themselves happy, not expecting a "when" to have this feeling (Comte-Sponville, 2005). P1's statement shows the value he places on being close to those he likes.

"Yeah, I try to be happy the moment I can [...]. With my granddaughter, with my great-grandsons, there's a 3rd coming... So, this is the happy moment, when I'm with my grandchildren, playing with them, I see my daughters happy, it makes me happy too." (P1).

However, some respondents said that they try to avoid displeasing their companion, for example, and people in general. This idea is very dangerous as people often idealize what the other person wants, and move in certain directions, against their will, running a great risk of not pleasing the other, either (Aerts; Ganzo, 2012). Concerning the ability to deal with feelings, emotions, and affections, Duarte (2014) shows that behavior and interpersonal relationships are influenced by feelings and emotions, so learning to understand and regulate one's own emotions helps to establish empathy and the necessary skills for relationships with others. P16, to avoid his wife's jealousy, excluded hundreds of profiles from his social networks, contrary to his desire but still ended up fighting with his partner.

"I have very few friends on Facebook nowadays. I think I had around 200 people, also on Instagram and stuff. But I've had almost 2000, 3000 people. And most of them were clients, but then it started, because of arguments: "Oh, so that's it, unfriend them." And "Let's unfriend, let's unfriend," and then it was like this, with very few people. Very few people." (P16).

P3 and P15 mentioned their effort to renounce their own will and make concessions, to create a friendlier atmosphere. From their reports, it seems that they were comfortable with these attitudes as their relationship with their partners has improved considerably.

"Ah, now, after everything l've been through in the group, I look for... I see if my wife is happy if we're happy with what's happening in our lives." (P3).

"I made a mistake, I had my share, she had hers, so I came, I participated, I learned a lot from this, my relationship with my wife that was nice improved a lot more because we learn. Sometimes she says something I don't like, but we don't have to argue. I wait for a minute or two after that... You talk again, breathe, take a walk, go out, come back, you know? That was very important to me." (P15).

Such behavior reveals a heightened degree of emotional intelligence on the part of these research 
participants since they were able to understand that the best attitude is to understand what is going on and put themselves in the other's place, rather than accusing. The inclusion of emotional intelligence in wellness studies is justified by the function of intra and interpersonal adaptation inherent to emotional intelligence, which can lead to better well-being (Goleman, 1997).

As for work and leisure, the interviewees also described what they do to be happy. Research has shown a positive relationship between a high rate of well-being and the organization of leisure time (how to keep extracurricular activities or not) and spending time with friends and physical activity. Doing nothing is negatively associated with well-being. The activities involving social interaction and the development of physical and intellectual skills are indicators of subjective well-being (Sarriera, Schütz, et al., 2014). Among those interviewed, most attributed a high degree of importance to professional and academic work and activities in the pursuit of their happiness, indicating them as opportunities to develop their potentials, pursue their purposes in life, and self-realization (Waterman, Schwartz, Conti, 2008). P11's response is an example:

"Yeah, I'm a hard worker. I like to fight to always have my savings, to always be able to help my children more, to give more assistance to my wife." (P11).
The interviewee P10 referred to the need to control the impulse at work to save quality time to leisure with family and friends:

"Yeah, I like it that way, what I'm doing now, on the weekends, it's taking off and going to the river, with everybody...." (P10).

Interviewees P13, P15, and P6 also pointed out the importance of investing in the quality of time and leisure together with their partners. They believe this helps to avoid fights and cultivate the relationship.

"I have a girlfriend, and there is little time left for leisure, but as much as possible, we try to make the time, we like to walk, stroll, and everything." (P13).

"It's not a party girl or something like that, so we go for walks when it's possible, or at least we go out to Porto Alegre when it's possible to take a trip." (P15).

"I'm a very calm person, you know and I'm very homely... And now with this new partner, I'm going out a little more." (P6).

Figure 2 condenses the most representative data of the interviewees' statements. Many references to the family and specifically to the companion in the statements belonging to the three subcategories of the survey can be observed.
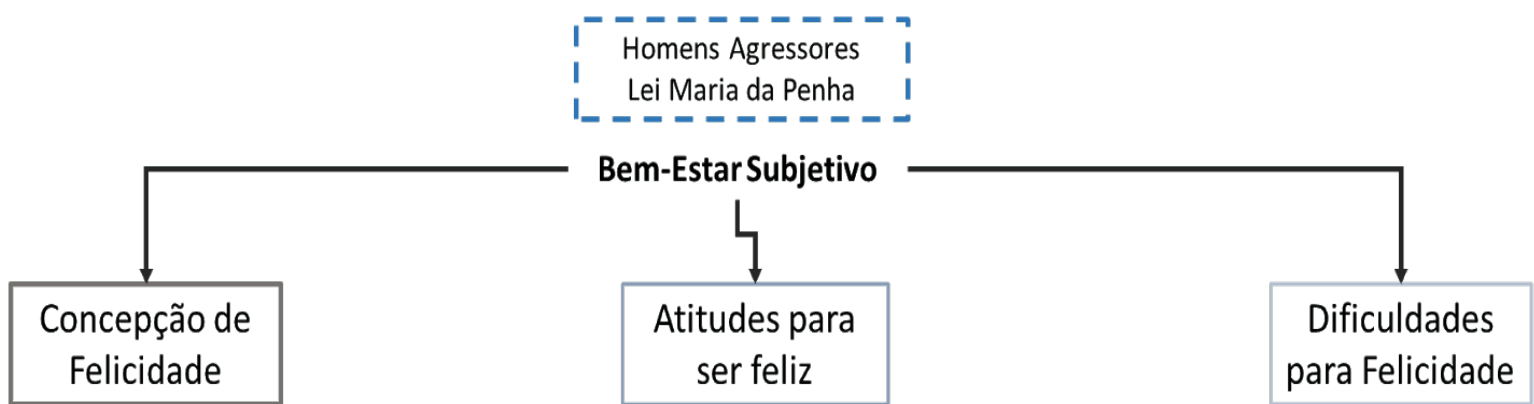

"Felicidade é ser feliz, estar bem consigo mesmo (P10).

"Primeiro comigo, né, assim, se eu não tiver bem comigo eu não vou ser feliz, né (P11)."'Eu, e acho que todas as pessoas estarem bem, em primeiro lugar, com elas mesmas (P15)."

"Eu acho que a maior felicidade que tem é essa: se dar bem, querer bem o próximo, como a gente quer o bem pra gente, a gente quer o bem pro próximo também, né? Já é uma felicidade que a gente tem de ver uma pessoa bem... (P12)"

"Ah, pra mim, felicidade, eu, como sou casado, é estar bem com a minha familia, né, com a minha esposa, com meus filhos, né, sempre tentando se dar bem com meus parentes e [...] (P3)".

"Ser feliz é viver com a minha família. Pra mim não tem mais nada feliz do que viver com a minha familia (P9)."

"[...] com todo o universo que eu lido, as pessoas, ... o trabalho... pra mim isso é felicidade, estar feliz. (P11)."

Penso que aqui poderias pegar uma fala mais significativa que relacionasse bem estar e trabalho.
"Á é muitas coisas, que eu, sinceramente, prefiro não entrar nesse mérito aí, porque eu tenho uma opinião sobre pessoas que vivem junto. A pessoa, a minha companheira, no caso, ela errou muito comigo e eu também errei com ela. A gente tá junto há mais de 40 anos. Então, alguma coisa, pra ela ficar esse tempo comigo, alguma coisa ela tem que ver em mim de bom, e eu a mesma coisa: eu tenho que ver alguma coisa, senão eu não estaria com ela até hoje, né? (P1)."

"Pois é, eu comecei pelo caminho errado. E eu fiquei muito depressivo, e fiquei usando o álcool também, junto (P13)."

"Olha, eu acredito que são brigas e essas coisas. Com todo respeito à minha esposa, ela tem um problema só que é grande: ela vai falar uma coisa pra ti, em vez dela falar numa boa, com calma, ela começa "B|B|B|B|", sabe? pra quê? Fala numa boa, com calma, não precisa, né? (P14)."

"Eu não fui agressor. Eu posso ter agredido com uma palavra só, que eu ainda recebi um portão nas costas, porque eu fui... era uma namorada que eu tinha e eu vi ela saindo de um motel, entendeu? E o que aconteceu é que eu fui na casa dela, nós tínhamos combinado e tudo, e eu olhei pra ela e perguntei: "tu não tem nada pra me falar?", "não, não tenho", "mas eu tenho, eu te vi saindo do motel", assim, assim.
"Olha, tchê, nada me atrapalha porque os obstáculos da vida a gente tem que ir resolvendo aos poucos, eu penso, assim, que não tem problema; pelo menos eu penso assim, né (P11)."

"Graças a Deus, não tenho nada a reclamar 'da vida (P12)."

Figure 2: Summary of the most representative data collected in the survey. 
The family and family life were the most frequently encoded items, when participants were asked about their concept of happiness, the challenges they encounter in being happy, and their attitudes in the pursuit of happiness. A distinction is made in this survey between occurrence and frequency, which corresponds to the number of respondents who mentioned each code and the number of times each code was mentioned, respectively. For example, the family code was mentioned by all 16 participants (occurrence) and appeared 33 times (which represents its frequency). This means that some mentioned it several times, referring to more than one subcategory analyzed. This is not the case with all codes, and in this proportion, it does not occur with any other, which is why the research highlighted the importance of the family for domestic violence offenders. Figure 3 illustrates these results.

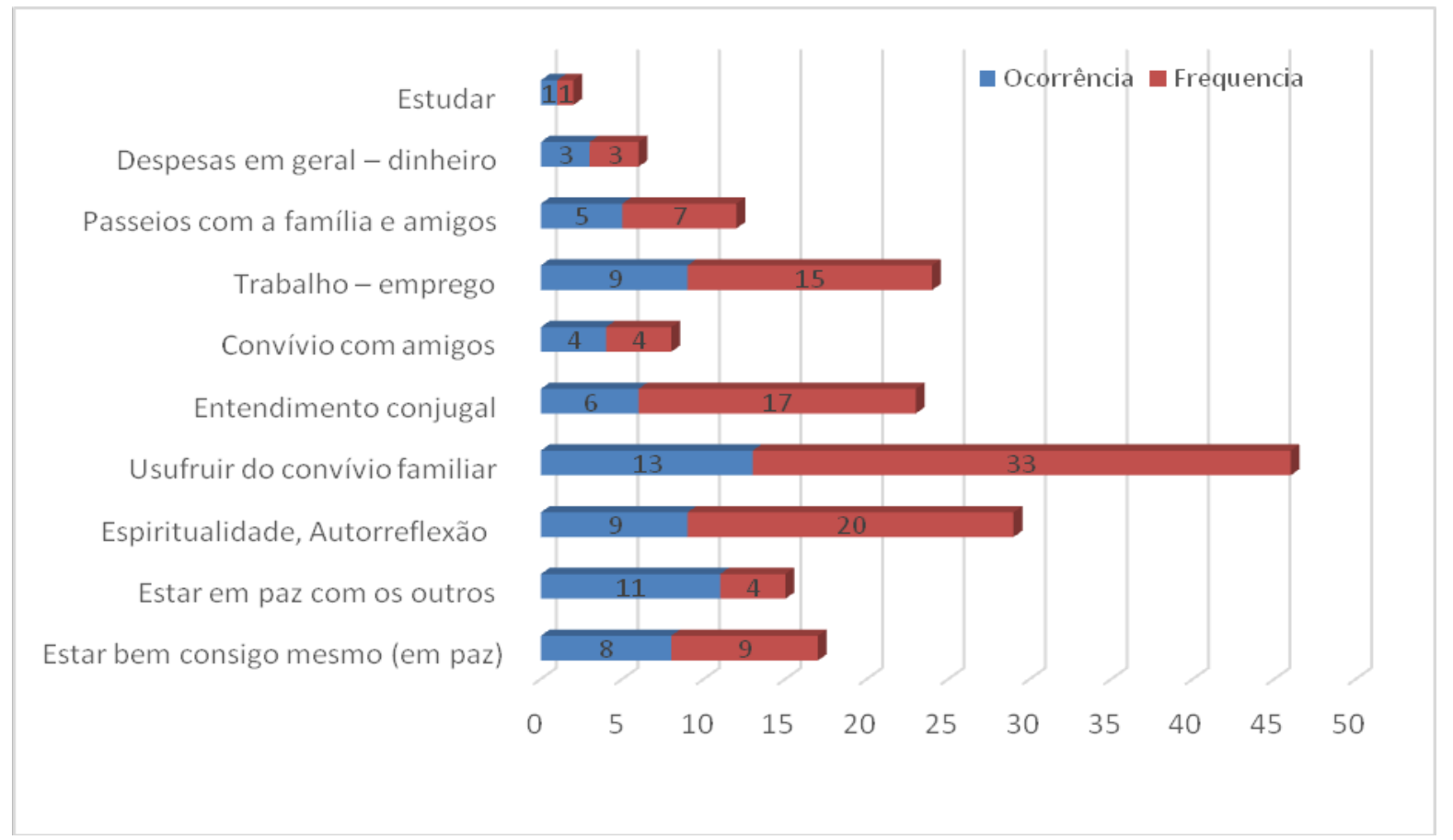

Source: The research

Figure 3: Occurrence and frequency of codes used in content analysis resulting from interviews with 16 men with restraining orders.

Each subcategory (as shown in Figure 1) was divided into three dimensions, within which the codes resulting from the analysis were inserted. The reference to the family occurred in the dimension relations with others in the subcategory, Conception of Happiness, in the dimensions, Relations with Others and Occupation of the subcategory, Challenges to be Happy, and again in the dimensions, Relations with Others and Occupation of the Attitudes to be Happier subcategory. Thus, out of nine possibilities of occurrence, the code associated with the family was present in five.

\section{Vil. Final Considerations}

The World Health Organization (WHO) recognizes domestic violence against women as a public health issue and as a serious problem to be recognized and addressed by both society and government bodies. Attributing the condition of women as the only victim will not solve the problem, it is necessary to consider the fact that men also suffer the consequences of expectations imposed by society, as they are deprived of living fully to their potential. Therefore, there is a need to seek new social relations, no longer governed by power and domination, but by reciprocity between the sexes.

The study on subjective well-being made it possible to organize the subcategories (Conception of Happiness; Challenges in being Happy; Attitudes to being happy) to relate the different conversations and feelings. In the field of happiness, the interviewees reported the dimension of their relationship with themselves with two codifications: being well with themselves and spirituality/self-reflection. These feelings increase with age, education, and consciousness, and decrease with neuroticism (unhappy feeling), according to Ryff (1989). In the relationship with others (family, friends, and spouse), the family has great importance, as does the relationship with the intimate partner, whether conjugal or not. Although having a dialogue with the partner is highlighted, the interviewees express difficulty in accepting that they are abusers. 
Within the Attitudes to being Happy subcategory, the challenges to achieving happiness are related to the person and the partner, that is, the acts of aggression are justified by the woman's behavior. The relationship between children and other family relationships can affect the achievement of happiness. The time spent at work and the low income affect the family relationships of those interviewed and consequently prevent them from being happy.

The word family was referred to in most dimensions by the participants. The phenomenon must be accompanied by all facets. This new look at health problems will make it possible to glimpse a scenario where men are part of the solution, and no longer just part of the problem.

Despite the limitations of the research, especially it being a field research, with geographical limitations, which may make inference difficult for the Brazilian male population, the study has important implications about profiling male abusers. They demonstrate a dissociation between their aggressive attitudes and consequences. They consider the family as a priority and do not understand their attitudes as an element of breaking up the home, often recognizing themselves as victims and not victimizers. Laws like Maria da Penha are essential to creating a legal base of protection for the real victims. But they alone will not be able to change the picture of violence, which has deeper social roots, which only continued education and awareness can resolve.

\section{References Références Referencias}

1. Aerts, D; Ganzo, C. (2012). A felicidade possível. Porto Alegre: Bororo25.

2. Assembleia Legislativa de Minas Gerais (2018). Violência contra a mulher. Belo Horizonte.

3. Barker, G. (2010). Trabalho não é tudo, mas é quase tudo: homens, desemprego e justiça social em Políticas Públicas. In: Medrano, B., Lyra, J., Azevedo, M. \& Brasilino, J. (org.). Homens e Masculinidades: práticas de intimidade e políticas públicas Recife: Instituto PAPAI.

4. Brissos-Lino, J. (2015). A desigualdade entristece (segundo um relatório internacional sobre a felicidade). Blogue mantido por José Brissos-Lino, 2015. Disponível em: https://brissoslino.wordpress. com/2015/07/27/a-desigualdade-entristecesegundo-um-relatorio-internacional-sobre-afelicidade/ Acesso: 30/05/2020

5. Bustamante, V. (2005). Participação paterna no cuidado de crianças pequenas: um estudo etnográfico com famílias de camadas populares. Cad. Saúde Pública, 21(6), 1865-1874.

6. Casas, F. (2011). Social indicators and child and adolescent well-being. Child Indicators Research, 4, 555-575.
7. Castaños-Cervantes S, \& Sánchez-Sosa J. J. (2015). Niñas y adolescentes en riesgo de calle: Bienestar subjetivo y salud mental. Revista CES Psicología. 8(1).

8. Castel, R. (1998). As metamorfoses da questão social: uma crônica do salário. Petrópolis: Vozes.

9. Cecarelli, P. R. (1998). A construção da masculinidade. Percurso. 19, 49-56.

10. Comte-Sponville, A. (2005). A felicidade, desesperadamente. SP: Martins Fontes.

11. Duarte, M. S. L. (2014). A influência da percepção da vinculação aos pais no uso de estratégias de regulação emocional em adolescentes. Unpublished master's thesis, Faculdade de Psicologia e Ciências da Educação. Universidade de Coimbra, Portugal.

12. Foucault, M.. (1994). Dits et écrits IV. Paris: Gallimard.

13. Goleman, D (1997). Inteligência emocional: a teoria revolucionária que redefine o que é ser inteligente. Rio de Janeiro: Objetiva.

14. Houskamp, B. M., Fisher, L. A., \& Stuber, M. L. (2004). Spirituality in children and adolescents: Research findings and implications for clinicians and researchers. Child and Adolescent Psychiatric Clinics of North America, 13(1), 221-230.

15. Lei Federal $n^{\circ}$ 11.340. (2006). Brasilia, 7 de agosto. Presidência da República.

16. Lima, R. F. F., Araujo, N. M. (2018). Bem-estar subjetivo de crianças e adolescentes: revisão integrativa. Cienc. Psicol., 12(2), 249-260.

17. Lucchetti, G., \& Lucchetti, A. L. G. (2014). Spirituality, religion, and health: Over the last 15 years of field research (1999-2013). The International Journal of Psychiatry in Medicine, 48(3), 199-215.

18. Medrano, B., Lyra, J., Azevedo, M. \& Brasilino, J. (org.) (2010). Homens e Masculinidades: práticas de intimidade e políticas públicas Recife: Instituto PAPAI.

19. Meneghel, S.N., Giugliani, E.J., Falceto, O. (1998). Relações entre violência doméstica e agressividade na adolescência. Cad. Saúde Pública, 14(2), 327-335.

20. Minayo, M.C.S. (2014). O desafio do conhecimento. Pesquisa qualitativa em saúde. 14 ed. São Paulo: Hucitec.

21. Musleh, M.H. (2013). O vitimizador. In: Seixas, M.RD.; Dias, M.L (Org.) A violência doméstica e a cultura da paz. Santos, SP: Roca. p. 171-182.

22. Narvaz, M. G., \& Koller, S. H. (2006). Mulheres vítimas de violência doméstica: compreendendo subjetividades assujeitadas. Psico 37, 7-13.

23. Palhoni, A.R.G, Oliveira, V.J., Villela, L.C.M., Penna, C.M.M. (2017). Representações de mulheres sobre qualidade de vida e sua relação com violência contra a mulher. Rev enferm UFPE, 11(4), 1701-8. 
24. Paschoal, T. (2008). Bem-estar no trabalho: relações com suporte organizacional, prioridades axiológicas e oportunidades de alcance de valores pessoais no trabalho. Tese de Doutorado em Psicologia, Universidade de Brasília, Brasília.

25. Pinto, A. D. C., Meneghel, S. N., \& Marques, A. P. M. K. (2007). Acorda Raimundo! Homens discutindo violências e masculinidade. Rev. Psico. 38(3), 238-245.

26. Ryff, C. D. (1989). Happiness is everything, or is it? Explorations on the meaning of psychological wellbeing. Journal of Personality and Social Psychology, 57(6), 1069-1081.

27. Saffioti, H. (1994). Conceituando gênero. In Saffioti, H., \& Muñoz-Vargas, N. Mulher brasileira é assim. UNICEF; Rosa dos Tempos. pp. 271-283.

28. Sarriera, J. C. (2004). Saúde, bem-estar espiritual e qualidade de vida: pressupostos teóricos e pesquisas atuais. In: E. F.B. Teixeira, M. C. Müller, \& J. D. T. Silva (Orgs.). Espiritualidade e Qualidade de Vida. Porto Alegre, Brazil: EDIPUCRS.

29. Sarriera, J. C.; Bedin, L. M. (2017). Psychosocial Well-being of Children and Adolescents in Latin America. New York: Springer Verlag.

30. Sarriera, J. C., Schütz, F. F., Galli, F., Bedin, L., Strelhow, M. R. W., \& Calza, T. Z. (2014). Bem- estar na infância e fatores psicossociais associados. Porto Alegre, Brazil: Editora Concórdia.

31. Scott, R.P. (2010). Homens, domesticidade e políticas públicas na saúde reprodutiva. In: Medrano, B., Lyra, J., Azevedo, M. \& Brasilino, J. (org.). Homens e Masculinidades: práticas de intimidade e políticas públicas Recife: Instituto PAPAI.

32. Sen, A. (1996). Capacidad y bienestar. In M. Nussbaum \& A. Sen (og.). La calidad de vida (pp.54- 83). México, México: F. C. E.

33. Soraggi, F., \& Paschoal, T. (2011). Relação entre bem-estar no trabalho, valores pessoais $e$ oportunidades de alcance de valores pessoais no trabalho. Estudos e pesquisas em psicologia, 11(2), 614-632.

34. Strey, M. N. (2000). Será o século XXI o século das mulheres? In M. N. Strey, F. Mattos, G. Fensterseifer \& G. C. Werba (Orgs.). Construções e perspectivas em gênero (pp. 09-18). São Leopoldo: Unisinos.

35. Toneli, M.J.F. (2010). Práticas de/na intimidade: o que queremos dizer com isso? In: Medrano, B., Lyra, J., Azevedo, M. \& Brasilino, J. (org.). Homens e Masculinidades: práticas de intimidade e políticas públicas Recife: Instituto PAPAI.

36. Vasconcelos, M.S., Holanda, V.R., Albuquerque, T.T. (2016). Perfil do agressor e fatores associados à violência contra mulheres. Cogitare Enfermagem, 21(1), 1-10.
37. Veenhoven, R. (2009). Medidas de felicidad nacional bruta. Intervención Psicosocial, 18(3), 279-299.

38. Waterman, A.S, Schwartz, S.J., Conti, R. (2008). The implications of two conceptions of happiness (hedonic enjoyment and eudaimonia) for the understanding of intrinsic motivation. Journal of Happiness Studies, 9, 41-79.

39. Zuwick, A. N. (2001). O corpo violado. Em P. K. Grossi \& G. C. Werba (Orgs.). Violências e gênero: coisas que a gente não gostaria de saber. Porto Alegre: Edipucrs. 